\begin{abstract}
Cracow Indological Studies
Vol. XXI, No. 2 (2019), pp. 239-257

https://doi.org/10.12797/CIS.21.2019.02.10

\section{Jacek Woźniak \\ jacek.wozniak@uw.edu.pl \\ (University of Warsaw, Poland)}

\title{
Lords of the Lord: \\ Crossing Boundaries between Human and Divine in Tamil Vaiṣnava Bhakti Poetry
}

SUMMARY: In the Tamil Bhakti tradition the devotees are generally referred to as 'servants/slaves [of God],' and this slave attitude is one of the main characteristics of their relation with God, their Lord. However, in the works of the $\bar{a} \underline{l} v \bar{a} r \mathrm{~s}$, Tamil Vaiṣnava poet-saints, one can find a few examples of the rather unusual situation in which devotees are presented not as slaves of God but actually as His Lords. Thus, exercising their authority over God, who is seemingly dependent on human actions, can be understood as a peculiar way of crossing traditionally recognized boundaries that exist between these two different realms (soul vs. God/human vs. divine). All these acts are supposed to be primarily the expressions of human love and the irresistible need to unite with the Lord, which eventually results in taking control over Him.

KEYWORDS: Tamil Bhakti, ālvārs, Viṣnu, Tirumanikaiyālvār, Nammāālvār, Tiruppāṇālvār

The title of my paper is a modification of the title of Vidya Dehejia's book (Slaves of the Lord. The Path of the Tamil Saints; 1988) about the twelve Tamil Vaiṣnava poet-saints from the early Medieval period, ca. $6^{\text {th }}-9^{\text {th }}$ century. In the Tamil Bhakti tradition, both Vaiṣnava and Śaiva, the devotees frequently refer to themselves by a technical term atiyār (in the first person singular atiyeñ), which is created by adding a pronominal ending to the noun ati ('foot/feet'). Thus, it can be descriptively translated as 'those, who are [always ready to serve] 
at the [God's] feet', and the English equivalents most often used for this term are 'servants' or even 'slaves,' as Dehejia has put it.

The twelve canonized Tamil Vaișnava poet-saints, who are the best examples of such '[God's own] slaves', are known by the name ā $\underline{l} v \bar{a} r$, which, traditionally, is supposed to mean 'the one who is immersed/ submerged/drowned/plunged [in the love of/for God]'. However, as argued by S. Palaniappan (Palaniappan 2004), ${ }^{1}$ this word comes most probably not from the verbal root $\bar{a} \underline{l}$ ('to sink, plunge, dive'; 'to be absorbed, immersed, overwhelmed'), but it derives from the verbal root $\bar{a} l$ ('to rule, reign over, govern'). Thus, the name $\bar{a} \underline{l} v \bar{a} r-$ contrary to the traditionally and generally accepted etymology — should rather be read not as 'the one who is immersed,' but 'the one who rules; the ruler, Master, the Lord,' which exactly agrees with the name of the only woman-poet among the $\bar{a} \underline{l} v \bar{a} r \mathrm{~s}$, who is known today as Ānțậl ('she who ruled').

It is interesting to note the shift in the name and hierarchical position of these Vaiṣnava poet-saints, who, while being 'slaves', at the same time are called by the Tamil Vaișnavas 'rulers/lords'. A few questions arise at this stage: How can slaves be called lords? And, more importantly, whose lords are they? Over whom do they actually rule?

In the Tamil poetry of the early Bhakti period one can find some interesting examples of this reversed situation, in which the devotees (who were supposed to be their Lord's slaves) play the role of lords of their God. Ruling over the Lord and exercising the authority over God can be understood as a peculiar way of crossing traditionally recognized boundaries existing between these two realms - of devotees perceived first of all in terms of slavery and of the divine being viewed as the Lord or Master of His slaves.

A. K. Ramanujan (Ramanujan 1993: 149) says that in Bhakti we can observe - to a certain degree - the breaking of different barriers (like those existing between castes, genders) and also some kind

Earlier, it was Friedhelm Hardy (Hardy 2001: 250-251) who probably was the first one to follow this line of argumentation. 
of a neutralization of "any distinction between sacred and profane in time and space." Thus, he continues, "the array of lord and servant (...) is maintained but in reverse."

Some traces of such a reversed attitude of devotees becoming their God's lords can be found in a few stanzas by the $\bar{a} \underline{l} v \bar{a} r \mathrm{r}$ in which devotees are shown as those who can somehow control their God. We can select at least six such situations in which the poets sing about: 1) possessing their God; 2) devouring and drinking Him; 3) the erotic relation with His body; 4) blackmailing Him; 5) their parental feelings towards Him; 6) enshrining Him in a place, etc. In all these situations the devotee, the true slave of the Lord, becomes the one who has some kind of power over God-from the rather inferior position he/she rises to the superior one.

\section{1) Possessing Him}

Possession is mostly understood as a state in which, as is believed, God or an evil spirit enters the body of a human being and temporarily takes complete control over it. So the main image is that of God entering the human body.

Hardy (Hardy 1994: 517) says that possession, so characteristic of the shamanic cults and actually a very popular form of communication with the divine in the village Hinduism of South India, is an element that is rather absent in the Bhakti tradition, which he analyzes mostly in the form of ecstatic Kṛnnaism as practiced by the Bengali movement started by Caitanya ( $15^{\text {th }} / 16^{\text {th }}$ cent.). As he writes (ibid.: 517$)$,

"cults of possession are, on the whole, associated with low-caste people and unrefined types of religion. Ecstatic Kṛșnaism, right from the beginnings $[\ldots]$ has operated on a much higher social niveau. $[\ldots]$ on the surface it might look as if the bhakta is possessed, but in reality it is the expression of a refined love towards an equally refined deity who has nothing to do with the vulgar cults of peasants."

However, as shown by Glenn Yocum (Yocum 1973), the shamanic practices which are closely related to the village religion and modes of worship of local Dravidian gods and goddesses played a very 
important role in the emergence of the popular Bhakti in South India which took place almost one thousand years before the Caitanya era.

Whatever the conclusions of the theoretical disputes on the relation between the village shamanic cults and the Brahmin-dominated Bhakti movement might be, we can accept that at least some forms of village religion infiltrated the poems by the $\bar{a} \underline{l} v \bar{a} r$ s and are traceable in their works.

The idea of God residing in the human body is not unknown to Indian classical thought. We can trace it back to the Upanișadic teachings about the oneness of the brähman and atman. The essential part of this idea is found in the South Indian Vaișnava (both Pāñcarātric and Śrīvaișnava) images of God Viṣnu, who, in the form of antaryāmin ('the inner controller') dwells in the hearts/minds of His devotees. In the poetry of the $\bar{a} \underline{l} v \bar{a} r$ s we can find many examples of this imagethey quite frequently mention Viṣnu entering into and abiding in their heart/mind/soul or body (e.g. Periya tirumoli 1.6.7, 1.10.8, 2.5.7, 3.5.6, 5.2.3, 7.2.5, 7.5.6, 7.7.2, 8.9.4, 9.10.8).

However, the question of possession understood as the act of entering the human body by God is more complicated and has one more interesting dimension. Steven Paul Hopkins (Hopkins 2003: 150-151) notes that "God both possesses and is possessed by the devotee. In extraordinary moments of religious ecstasy, the normal hierarchical relation is reversed." We can add - the Lord (God) gets His lords (devotees) and becomes dependent on them. He who rules is now being ruled by others.

For example, Tirumañkaiyālvār in his Periya tirumoli 1.10 .9 says:

\section{vantāy en manam pukuntāy manni nin̄rāay}

nantāta koluñ cuțarē è̉kal nampī

cintāmaṇiyē tiruvēinkațam mēya

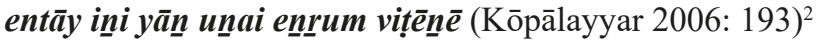

2 I am using the edition of the Periya tirumoli by T. V. Gopal Iyer (Kōpālayyar 2006), in which sandhi rules are not applied in the printed text. 
You came, entered my heart and stayed [there] forever.

O great unextinguished Flame! Our Lord!

$\mathrm{O}$ wish-fulfilling Gem! O my Father who dwells in the sacred Vēnikațam!

From now on I will never let you [go]!

As we can see, God enters the heart of the poet and He stays there. What is more important is that the poet does not want to let Him go out of his heart. After entering the poet's body, Viṣnu was supposed to take control over it (as it normally happens in the ordinary act of possession), but it has happened the other way round-it is the poet who unexpectedly took control over Viṣnu! Who is the Lord of whom and who takes control over whom? It seems that Vișnu was caught in a trap and will not be released easily. Now He is dependent on the poet, who has some advantage over Him. God is now captured, entrapped, imprisoned, and He cannot leave the poet's body on His own. It is the poet who decides, who establishes his rules and has control over Viṣnu's further activities.

So the possession in this case is something different than the possession of a purely shamanic kind. It is understood here not as the act of entering God's body, but as the act of taking control over Him, His decisions and activities.

Some $\bar{a} \underline{\underline{l}} v \bar{a} r \mathrm{r}$ in direct contact with their God have a rather passive attitude towards Him and just allow Him to possess their bodies and minds. As Hardy (Hardy 2001: 435) and Hopkins (Hopkins 2003: 151) in their two separate analyses of Tiruppāṇālvār's Amalanātipirān (in which we have a description of Viṣnu's body/image starting from the feet and ending with His head) observe, God enters and possesses the poet through his senses, especially through his eyes. ${ }^{3}$ So it can be said that through his own senses the poet "absorbs"

Eye contact is very important in Hinduism. Darśana (taricanam, Skt. darśana; 'seeing, see, look, view') is one of the major ritual acts involving looking at the image of God in the final stage of the püjā. Aratti (Skt. ärati), which is the act of offering light to the deity, is one of the main rituals in the temple; 
the image of Viṣnu. On the one hand, it is the active God who looks at the poet (we have to remember that it is believed that temple images or icons do have their eyes opened and they can see- the ritual opening of idol's eyes (Skt. akssyunmesana) is a necessary one to make it an object of worship (Malamoud 1998: 210; Masilamani-Meyer 2004: $153,162,180$ ) and then penetrates his body. On the other hand, it is also the poet who is active and not so passive as mentioned before because it is him who performs this act through his own senses/eyes. Without the act of being watched God could not get inside Tiruppāṇālvāar's body. It is not God who is entering the poet's body at His own will, but He is somehow forced to do it. He is absorbed into the poet's body after being watched by him-He has no other choice. And this is what Hardy (Hardy 2001: 435) writes about Tiruppānālnāra's description of Viṣnu's body: “The Ālvār's senses, or better his eyes, seem to devour each part of the body and bring them into his soul, where they cause great ecstasy." It is worth noticing that the words used by Hardy clearly indicate that it is actually the poet who actively devours the God, which leads us to the second situation in which the devotees can become Lords of their God.

\section{2) Devouring and drinking God}

The metaphor of devouring/eating (unnutal) or swallowing (vilunikutal) is the second one: in the works of the $\bar{a} \underline{l} v \bar{a} r$ s we have examples of the devotee taking active control over God. In the Vaiṣnava tradition there are a few mythological representations of God who contains the whole world within Himself (in His mouth or belly). The idea of God-creator

it symbolically represents the entire ritual of $p \bar{u} j \bar{a}$. In addition, the devotees touch their eyes with their hands, with which they previously touched the burning camphor flame which illuminated the image of God on the altar. Touching the eyes with the tips of the fingers which are still warm after touching the fire results in uniting the devotee with God. In the light of the burning of camphor God and devotee can see each other (cf. Eck 1985: 6-7), and then unite. The power and grace of God, which manifests itself in the flame of camphor, can penetrate into the hearts of believers through their eyes (Fuller 1992: 73). 
eating the world which He had created is not new, and it is wellknown even to early Indian thought, as it appears in the Brāhmanas (Prajāpati creates and eats the worlds) and in the Bhägavadgita (Viṣnu keeps the world in His mouth). The most famous in the Vaișnava tradition is the image of a young Kṛṣna in whose open mouth Yaśodā, His foster mother, sees the whole universe (O'Flaherty 1980: 95). Similarly, sage Mārkaṇdeya relates how he got into the belly of Viṣnu/ Krṣna, which had no end, and it contained the whole earth and all people (O'Flaherty 1980: 96; Carman and Narayanan 1989: 160; Zimmer 1990: 41-50; Warder 1994: 533). As John Carman and Vasudha Narayanan (Carman and Narayanan 1989: 170) write, the act of eating is twodimensional and it has two directions. ${ }^{4}$ God not only devours the world (including His devotees), but He can also be devoured. In the poetry of the $\bar{a} \underline{l} v \bar{a} r$ s this metaphor of devouring or eating God, who previously had eaten the whole world, is present especially in the works of Nammālvār (Hopkins 2003: 150). Relating to these metaphorical descriptions of the act of eating, Ramanujan (Ramanujan 1993: 150) even uses the expression "mutual cannibalism," while Carman and Narayanan (Carman and Narayanan 1989: 174) speak about "mutual inclusiveness," which stresses the belief that God, while devouring/ eating the whole world, consumed all His devotees too. Being previously eaten by Him, in turn they eat Him now, being hidden inside Him, and at the same time He eats them again while staying inside them (due to the concept of antaryämin - Vișṇu always stays in the hearts/ minds of His devotees). In Nammālvār's Tiruvāymolni 9.6.4.a-b we can read:

4 Such possible two-dimensionality or reciprocity of the relations between God and devotees can be assumed even from the etymology of the name used for 'bhakti.' As observed by Marzenna Czerniak-Drożdżowicz (Czerniak-Drożdżowicz 2010: 143): "(...) bhakti means, first of all, distribution, partition, but also sharing, namely giving but also receiving in return. Through these meanings bhakti can be understood as a kind of a mutual relation, in which the devotee offers his attention and devotion to god, but in which he can expect his share and his reward." 
[...] tannnul anaittulakum nịka

nerimaiyāl tāñum avarrulnị kumpirān $\underline{n}^{5}$

As all the worlds remain inside Him,

$\mathrm{He}$ is the Lord, who remains inside them as per the rule.

Nammālvār in this poem, i.e. Tiruvāymoli 9.6 , presents the heroine who is in love with Viṣnu. In a few stanzas she openly admits that she suffers since He has eaten her up (en uyir unțān ; 'he ate my life/soul', 9.6.3.b; ennai murravum tān unțān; ' he has eaten me completely', 9.6.8.b). But, interestingly, she also has the desire to consume Him. In 9.6.10 we can read (cf. translation by Ramanujan [Ramanujan 1993: 150-151], and by Clooney [Clooney 2014: 101]):

\section{vārikkoṇ țunnai vilunikuvan kāṇil eñru \\ arvurra ennai yoliya en nilmunnam

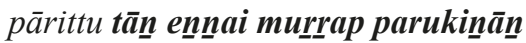 \\ kārokkum kāțarai yappan kațiyan̄e}

I had the desire that "If I see [You], I will grasp with avidity and swallow You" but desiring [this] before me, He fully drank me.

The Father of Kāttkarai, who is like black clouds, is a cruel One.

The heroine had expressed the desire to swallow God. She wanted to scoop Him in her hands (as is the customary way of taking food in South India), and then simply consume Him. But, to her surprise, He was faster than she, and actually it was He who completely drank her up. No doubt this metaphor of eating stands for the love the heroine feels for God and that is why she has a desire to eat/drink Him. However, Viṣnu comes first to drink her as He is the one who loves all His devotees. This is a good example of the idea expressed by A. S. Woodburne (Woodburne 1925: 66), who concludes his essay on God in Hinduism, saying: "The hymns of the Śaivite and Vaishṇavite

$5 \quad$ I am using the text of the Tiruvāymoli from the edition of the Nâlāyira tivviyap pirapantam by Ki. Vēṅkațacāmi Rețtiyār (Vēnnkaṭacāmi Rețtiyār 2000). 
saints reiterate the common experience of man, that when he seeks for God, he finds God already seeking for him."

We have seen so far that the heroine wanted to consume her God, but she could not do it since He came first and drank her. But this act of active drinking/eating God by the devotee does really happen in Nammālvār's poetry. Carman and Narayanan (Carman and Narayanan 1989: 170) notice that in the Tiruvāymoli 1.7.3 Nammālvār says that he is actually "drinking" the Lord, which gives him liberation:

āyar koluntāy avarāl puțaiyuṇnum

māyap pirānaiyen mānikkac cōtiyai

tūya amutaip parukip paruki en

māyap piravi mayarvarut tēnē

I have cut [the bonds] of ignorance [arising from] my illusory birth by drinking again and again the pure nectar, The Lord of Māyā, [who is brilliant like] the shine of ruby, who as the scion among cowherds was beaten by them [for stealing butter].

As we can see, constant drinking (parukip paruki) of Kṛ̣na, who is pure nectar (amutu), has given Nammālvār liberation from this world. The Tamil word amutu derives from Sanskrit amrta 'ambrosia, nectar of gods.' In Tamil it has also the meaning of 'food, especially boiled rice, the water, and the sweetness' (Tamil Lexicon 1982: 107). ${ }^{6}$ Again in Tiruvāymoli 6.10.3.b Nammālvār says (cf. Carman and Narayanan 1989: 171):

eṇnam pukuntu tittikkum amutē imaiyōr atipatiyē

O amutu which enters [my] mind and tastes sweet! O Lord of the Celestials!

Viṣnu who is the amutu for the poet, i.e. his food, tastes very sweet and is just delicious to eat (tittikkum). The poet is explicitly saying that

6 In the dialect of Tamil Vaiṣnavas amutu means 'food; water,' and amutam 'the taste' (Vainava urainatai 2001: 102), and they tend to add this word as a suffix to the names of any other dish (Jagadeesan 1989: 71). 
he is eating his God in Tiruvāymoli 6.7.1.a-b, where the anonymous heroine declares (cf. Carman, Narayanan 1989: 171):

uṇnuñ cōru parukunīr tinnnumver rilaiyumellām

Kaṇnan emperumā ñen rēékaṇkal nìrmalki

"Kaṇnan, Our Lord, is everything, the rice [I] eat, the water [I] drink, the betel [I] chew." Having said [these words her] eyes filled with the tears.

In this example we can see that Kaṇnan (Kṛ̦ṇa) is a staple food for the heroine and she cannot live a day without Him. Food stands here metaphorically for God's love, without which the devotee cannot survive.

What has been labelled above as "mutual cannibalism" can well be exemplified by the words of Tirumankaiyālvār, who, in stanza 10.4.1 of his Periya tirumoli, describes the scene of feeding the toddler (Kṛșna) by His (foster) mother saying this:

[...] en mulaittațam tannnai vāñki nin vāyil mațuttu Nantan perap perra nampī nān ukantu uṇnum amutē entai perumān̄ē uṇnāy en ammam cēmam uṇnāày (10.4.1.b-d)

O Lord whom Nanda got to beget! My Father! My Lord! O amutu which I eat with pleasure! [Come and] eat the welfare from my breast, taking my breast [and] place [it] in your mouth, suck [it]!

It is overtly expressed that the act of eating is characterized by a mutuality of action. The mother feeds the baby whom in turn she-metaphorically - is eating herself. Kṛșna’s body is nectar for her and she wants Him to eat from her body as well.

There only exists a thin boundary line between the poetical expressions for eating and the erotic so we can now easily move to the next situation in which the $\bar{a} \underline{l} v \bar{a} r$ s become the Lords of Viṣnu.

\section{3) The erotic}

Carman and Narayanan (Carman and Narayanan 1989: 171-172) emphasize the erotic nature of the act of eating God by the poet-devotee. 
As they write, Nammālvār uses words that in addition to their main meaning ('food') have obviously sexual connotations. For example amutam in the compound vayamutam ('nectar from the mouth') means 'a kiss' (Tiruvāymoli 10.3.5.c), ${ }^{7}$ or the verbal root parimāru means first of all 'to distribute, to serve, as food to guests', but also 'to copulate with, have sexual intercourse'. The act of joining God, or becoming one with Him that takes place as a result of His consumption is described by means of the verb punar ('to join, unite; to associate with, keep company with'), having also the meaning of sexual intercourse ('to copulate'). The poems of the $\bar{a} \underline{\underline{l}} v \bar{a} r \mathrm{~s}$ frequently follow the conventions of Tamil classical literature, where the erotic themes (akam) were very important. The erotic dimension of their love towards God is noticeable in many of their songs, where they praise God's beautiful body. And their feeling of love is in most cases reciprocated by Him. We can thus say that the devotee, due to the immense love, can become the Lord's lover and have some power over Him in this respect.

Sometimes it happens that love is unfulfilled and then the feelings of despair, distress, and desperation can appear, which may lead even to the situation of blackmailing the lover who does not reciprocate the passionate feelings.

\section{4) Blackmailing Him}

In the works of the $\bar{a} \underline{l} v \bar{a} r \mathrm{~s}$ we have a few references to the riding on the matal, which was a practice known from classical Tamil poetry. As I explained elsewhere (Woźniak 2013: 357-358), “according to the stanzas, a disappointed lover, not able to meet his beloved and fulfill his desires, was riding on a palmyra stem, or on the figure of a horse designed out of palmyra fronds (Zvelebil 1974: 106). A threat to commit a matal, or to ride a mațal in public, was an essential but most extreme device to achieve his main goal - to meet his beloved once again. The custom was rather degrading and humiliating for the hero

7 It rather means 'saliva', as noted by the anonymous reviewer of my paper. 
(Dubianski 2000: 111; Zvelebil 1986: 22), but his primary intention was indeed to threaten the girl, so that she would agree to meet him immediately, frightened by the possible scandal and its future consequences." In a few poems from the Bhakti period we have the reversed situation - it is the heroine who threatens Viṣnu with performing the act of riding the matal if He will not accept her love. In her threat expressed in Tirumañkaiyālvār's Periya tirumațal, she openly poses a strong condition:

kalnaviltōl kālaiyaik kanțu ānku kaitolututu

en nilaimai ellām arivittāl emperumān

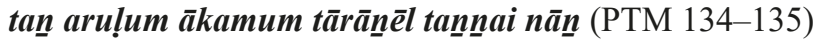

$[\ldots]$

... ulaku ariya ürvan nā̄n $[\ldots]$

manniya pūm peṇnai mațal (PTM 148)

Having seen the bull with the arms being said to be [strong] as rocks, having worshipped [Him] there, and letting Him, Our Lord, know all about my state [of mind], then, if He would not give [me] his grace and body, I [...] will wander around on the palmyra-palm matal to let the world know [about his ways]. (tr. Woźniak 2013: 363)

The heroine is desperate and she would do anything to meet her lover again, even if her behaviour may harm Him. She knows about Kṛ̣ṇa's misdeeds and His mischievous character and she is ready to use her knowledge against Him. We can easily assume that a person who threatens God and is thus God's blackmailer has some power and control over Him.

\section{5) Parental feelings towards Him}

Another possibility for taking control over God, a kind of specific way of capturing Him by the devotee, is expressed in Bhakti poetry by showing parental love towards God who is perceived as a child (vätsalya bhāva) ${ }^{8}$

8 Poets basically address Viṣnu as their beloved, master, lover, or child, as enumerated by Narayanan (Narayanan 1987: 3-4). 
As noticed by Narayanan (Narayanan 1987: 31), emotions in such cases are reversed and "the protector seems to need protection." It is assumed that God devours the world in order to protect it within His body. Placing the universe in Vișnu's stomach/belly corresponds to His main cosmological function, which is the protection of the world. Carman and Narayanan (Carman and Narayanan 1989: 170) compare this situation to a pregnant woman who protects the unborn foetus in her body.

Tirumankkaiyālvār mentions this in his Periya tirumoli 11.6.6.a-b, where it is stated that during the destruction of the world in the diluvian floods, Viṣnu, as a mother, hid all the people in His belly, so that they could survive:

pēy irukkum nețu velllam peru vicumpin mìtu ōtip peruku kālam

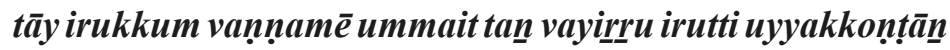

At the time when the large floods, [during which] demons [only] exist, flooded on the high sky, He saved you, having placed [you] in His belly, just like a mother does.

In the same way, acting as His mother, the devotee can protect his God. Hopkins (Hopkins 2003: 151) argues that the feeling of love (anpu) in the $\bar{a} \underline{\underline{a}} v \bar{a} r \mathrm{r}$ ' poetry is associated not only with physical love, but also with a parental one.

Obviously accepting the attitude of a parent (Ate 2011: ix) is not an expression of 'seizure' or 'possession' as was in the case of a trance experienced by the devotee, but certainly the poet gains some advantage over his God in terms of exercising parental authority over Him, which is mainly manifested in the form of a devotee's concern for the welfare of God and the unconditional love felt for Him.

Interestingly, in some stanzas dealing with the vätsalya bhāva theme there are still strong echoes of anxiety and fear of God, or at least of His unlimited and unpredictable powers, who at the same time is perceived as poet's own child, the gentle and innocent boy. For example, in Periya tirumoli 10.7.8-9 Yaśodā, Kṛ̣ṇa's foster mother, 
is seen as reprimanding her troublesome and yet beloved son Kṛșna, and at the same time she is afraid of scolding Him too much, since she knows that $\mathrm{He}$ is an extraordinary child with many superhuman powers which make her anxious (cf. Woźniak 2016: 148-149).

Another interesting theme although rather absent in the poetry of the $\bar{a} \underline{a} v \bar{a} r \mathrm{~s}$ but closely related to the topic of taking parental authority over God is the idea of God present in the form of arcā, or temple icon (cf. Narayanan 1985), as being a doll, or puppet (Hopkins 2003: 149-150). The best example of this is mentioned in Koyil oluku, the medieval chronicle of the temple in Sriirankam. When the Muslim invaders took the processional icon of Viṣnu from Śrīrañkam to Delhi in the $14^{\text {th }}$ century, the local princess was playing with Him as if He was a doll. The girl was in love with her new toy and when the icon returned to South India, she followed Him there (Davis 2004: 138).

Another passage of description, this time regarding the processional statue of Viṣnu from Mēlukōtẹ in Karnataka, is contained in the Śrīvaișnava hagiography Ârāyirappați kuruparamparāprapāvam by Pinpalakiya Perumāl Jīyar (ca. $13^{\text {th }} / 14^{\text {th }}$ cent.), according to which it was Rāmānuja who went to Delhi to get the stolen icon back. When he and the sultan arrived at the princess's room, seeing Rāmānuja in person, the icon of Viṣnu happily ran up and sat on his lap (Narayanan 1985: 57; Hopkins 2003: 149). In order to confirm the identity of the idol which he was looking for, Rāmānuja asked Him a question: "Are you my dear son?" (ennutaiya celva pillaiyō) (cf. Narayanan 1985: 57). Again, one can see here the parental attitude towards God understood as one's own son.

The idea of the temple icon leads us to the next situation in which the devotees can control God. This time it may be achieved by means of placing and enclosing Him in the temple building surrounded by high walls.

\section{6) Enshrining Him in a place}

Such specific reduction, or limitation of God's power and freedom, is undoubtedly associated with the Dravidian perception of divinity, 
which was adopted and included in the South Indian cult of Bhakti, dominated later by Brahmin tradition. The most important notion is the classical Tamil concept of the anainku, which has been differently explained by scholars. Frequently it is described as an immanent force of nature, which is identified with divine power, especially of female character. Without going into the ongoing debate about the multidimensionality of the concept (e.g. Rajam 1986), it should be noted that ananku has two important features: the ambivalence and the ability to focus on and penetrate certain places and objects.

George Luzerne Hart (Hart 1976: 321) understood anankku as "potentially dangerous sacred power" which he attributed mainly to women. In his opinion, it is they who had this power which was latent, but in certain situations, it could reveal itself and then be quite dangerous (Hart 1973: 236). Sacred female power, anankku, was accumulated mainly in women's breasts ${ }^{9}$ and hips (ibid.: 238-239). Ananku, as a potentially dangerous power, could cause damage and therefore should be kept under control (Hart 1976: 321). One of the forms of controlling the anainku was enclosing it in the sacred space which was the temple. In many cases, the poetry of the $\bar{a} \underline{l} v \bar{a} r \mathrm{~s}$ is related to temples as is the praise of temple icons, which constitutes the main body of the poems. When singing about different incarnations of Viṣnu, the $\bar{a} \underline{\underline{l}} v \bar{a} r \mathrm{r}$ always refer to His localized forms and names. He is the Lord of a peculiar place understood as His private house (koyil; 'house of the Lord', e.g. the temple). He resides there permanently, and the place/temple itself is often identified with Him (Woźniak 2018: 28). Thus, poems praising the Lord and His place of residence do make Him immobile, they apparently limit His activities inside the temple precincts. It is only the devotees who allow their God to leave the temple for a short time during festivals (vila a) , when

9 The power contained in the female breasts is visible in the episode from the classical epic Cilappatikäram when Kaṇnaki, devastated after the undeserved death of her husband, cuts off her breast and throws it onto the city of Maturai, which is then completely burned. 
the temple icon is carried throughout the town/village in a procession (ulā) and taken back to His 'house' after the festival is over.

\section{Conclusions}

In the Tamil Vaiṣnava Bhakti poetry we can see how hierarchy changes and those who were inferior (slaves) can eventually become the superior ones (Lords). The devotees, who love their God and are His slaves, can also exercise some power over Him. They can take control over Him, absorb Him into their bodies, devour Him, threaten Him when $\mathrm{He}$ is not acting according to their expectations, can even physically control Him by enclosing Him up within temples or treat Him as a toy. We can say that those who are slaves of the Lord may become the lords of the Lord, who, nevertheless, loves them so much that He allows them to do all these things to Him. After all Bhakti is sharing the emotions and feelings between the two parties: God and His devotees, the Lord and His 'lords'.

\section{References}

Ate, L. 2011. Yaśodā's Songs to Her Playful Son, Krṣna. Periyālvār's $9^{\text {th }}$ Century Tamil Tirumoli. Woodlands Hills: South Asian Studies Association.

Carman, J. and V. Narayanan. 1989. The Tamil Veda. Pillāan's Interpretation of the Tiruvāymoli. Chicago-London: The University of Chicago Press.

Clooney, F. X. 2014. His Hiding Place Is Darkness. A Hindu-Catholic Theopoetics of Divine Absence. Stanford: Stanford University Press.

Czerniak-Drożdżowicz, M. 2010. Bhakti in the Pāñcarātra Tradition-

Some Remarks. In: Cracow Indological Studies, 12: 141-171. 
Davis, R. H. 2004. A Muslim Princess in the Temples of Vișnu. In: International Journal of Hindu Studies, 8(1-3): 137-156.

Dehejia, V. 1988. Slaves of the Lord. The Path of the Tamil Saints. New Delhi: Munshiram Manoharlal Publishers Pvt. Ltd.

Dubianski, A. M. 2000. Ritual and Mythological Sources of the Early Tamil Poetry. Groningen: Egbert Forsten.

Eck, D. L. 1985. Darśan. Seeing the Divine Image in India. Chambersburg: Anima ( $1^{\text {st }}$ ed. 1981).

Hardy, F. 1994. The Religious Culture of India. Power, Love and Wisdom. Cambridge-New York: Cambridge University Press.

Hardy, F. 2001. Viraha-Bhakti. The Early History of Kṛșna Devotion in South India. New Delhi: Oxford University Press ( $1^{\text {st }}$ ed. 1983).

Hart, G. L. 1973. Woman and the Sacred in Ancient Tamilnad. In: The Journal of Asian Studies, 32(2): 233-250. https://doi.org/10.2307/2052342.

Hart, G. L. 1976. The Relation between Tamil and Classical Sanskrit Literature. Wiesbaden: Otto Harrassowitz.

Hopkins, S. P. 2003. Singing the Body of God. The Hymns of Vedantadeśika in Their South Indian Tradition. New Delhi: Oxford University Press ( $1^{\text {st }}$ ed. 2002).

Jagadeesan, N. 1989. Collected Papers on Tamil Vaishnavism. Madurai: Ennes Publications.

Kōpālayyar, Ti. Vē. (ed.). 2006. Tirumañkaiyālvōar aruliya panuval ăranul Periya tirumolii. Periyavāccān Pilllai uraiyin tamilākkam. Vol. I-II. Tañcāvūr: Teyvac Cēkkilāar caivacittāntap pāțacālai.

Malamoud, Ch. 1998. Cooking the World. Ritual and Thought in Ancient India. D. White (transl.). Delhi: Oxford University Press ( $1^{\text {st }}$ ed. 1996).

Masilamani-Meyer, E. 2004. Guardians of Tamilnadu. Folk Deities, Folk Religion, Hindu Themes. Halle: Verlag der Franckeschen Stiftungen zu Halle. 
Narayanan, V. 1985. Arcāvatāra. On Earth as He Is in Heaven. In: J. P. Waghorne and N. Cutler (eds). Gods of Flesh / Gods of Stone. The Embodiment of Divinity in India. Chambersburg: Anima: 53-66.

Narayanan, V. 1987. The Way and the Goal. Expressions of Devotion in the Early Śri Vaiṣnava Tradition. Washington, D.C.: Institute for Vaishnava Studies / Center for the Study of World Religions, Harvard University.

O'Flaherty, W. D. 1980. Inside and Outside the Mouth of God: The Boundary between Myth and Reality. In: Daedalus, 109(2): 93-125.

Palaniappan, S. 2004. Ālvār or Nāyan̄ār: The Role of Sound Variation, Hypercorrection and Folk Etymology in Interpreting the Nature of Vaișnava Saint-Poets. In: J.-L. Chevillard and E. Wilden (eds). South-Indian Horizons. Felicitation Volume for François Gros on the Occasion of His $70^{\text {th }}$ Birthday. Pondicherry: Institut Français de Pondichéry/École Française d'Extrême-Orient: 63-84.

Rajam, V. S. 1986. Anankku. A Notion Semantically Reduced to Signify Female Sacred Power. In: Journal of the American Oriental Society, 106(2): 257-272. https://doi.org/10.2307/601590.

Ramanujan, A. K. 1993. Hymns for the Drowning. Poems for Viṣnu by Nammālvār. New Delhi: Penguin Books ( $\left(1^{\text {st }}\right.$ ed. 1981).

Tamil Lexicon. Vol. I-VI with the Supplement. 1982. Madras: University of Madras ( $1^{\text {st }}$ ed. 1924-1936).

Vainava urainațai varalārru murait tamillp pērakarāti. Vol. I-III. 2001. Cennnai: Cānti cātañā.

Warder, A. K. 1994. Indian Kāvya Literature. Vol. IV. The Ways of Originality (Bāna to Dāmodaragupta). Delhi: Motilal Banarsidass Publishers Private Limited ( $1^{\text {st }}$ ed. 1983).

Vēnatạacāmi Reț̣iyār, Ki. (ed.). 2000. Mayarvarara matinalam arulappeṛra ālvārkal arulicceyta tamil vêtamākiya Nālāyira tivviyap pirapantam. Cennnai: Tiruvēnikațattān tirumannram (1 $1^{\text {st }}$ ed. 1973). 
Woodburne, A. S. 1925. The Idea of God in Hinduism. In: The Journal of Religion, 5(1): 52-66. https://doi.org/10.1086/480483.

Woźniak, J. 2013. Tirumañkaiyālvār's Mațal Poems and Social History of Early Medieval South India. In: Cracow Indological Studies, 15: 355-373.

—. 2016. The Poet as God's (Foster) Mother. Reading the Yaśodā Verses from Tirumañkaiyālvār's Periya tirumoli 10.7. In: O. Vecherina, N. Gordiychuk and T. Dubyanskaya (eds). Tamil tanta paricu. The Collection of Articles in Honor of Alexander M. Dubyanskiy. Moscow: Russian State University for the Humanities: 140-156.

- 2018. God as a Place of Destination. On the Urge to Go and Praise the Lord-(of the)-Place in Tirumañkaiyālvār's Periya tirumoli. In: D. Stasik and A. Trynkowska (eds). Journeys and Travellers in Indian Literature and Art, vol. 2: Vernacular Sources. Warsaw: Dom Wydawniczy Elipsa: 23-34.

Yocum, G. E. 1973. Shrines, Shamanism, and Love Poetry. Elements in the Emergence of Popular Tamil Bhakti. In: Journal of the American Academy of Religion, 41(1): 3-17. https://doi.org/10.1093/ jaarel/XLI.1.3.

Zimmer, H. 1990. Myths and Symbols in Indian Art and Civilization. Delhi: Motilal Banarsidass Publishers Private Limited ( ${ }^{\text {st }}$ ed. 1946).

Zvelebil, K. V. 1974. Tamil Literature. Wiesbaden: Otto Harrassowitz.

—. 1986. Literary Conventions in Akam Poetry. Madras: Institute of Asian Studies. 